\title{
PENGARUH PENGGUNAAN MODUL KONTEKSTUAL BERBASIS \\ MULTIREPRESENTASI PADA PEMBELAJARAN HUKUM GRAVITASI NEWTON TERHADAP PEMAHAMAN KONSEP SISWA
}

\begin{abstract}
Adila Ayu Verlina*, Chandra Ertikanto, Ismu Wahyudi
FKIP Universitas Lampung, Jl. Prof. Dr. Soemantri Brojonegoro No. 1

*email: adilaverlina@gmail.com

Received: $28 \mathrm{Mei} 2018$ Accepted: 4 Juni 2018 Online Published: 4 Juni 2018

Abstract: Effect Of Use Of Contextual Module Based On Multirepresentation In Legal Learning Newton Gravity On Understanding Student Concepts. This study aims to describe the effect of the use of multirepresentation contextual module on learning Gravity Newton Law on understanding the concept of students. This research was conducted at SMAN 14 Bandar Lampung with Quassy Experimental design type pretest-posstest control group design. The result of $N$-gain test that has been done shows that the average of $N$ gain from class using multideprescription contextual module is higher that is 0,75 with high category. Hypothesis test results obtained that there is a difference in understanding the understanding of physics concepts between students who learn to use multirepresentative-based contextual module with the use of school print books. To measure of understanding of the concept of student using Certainty of Respone Index (CRI.) The value of students concept understanding is shown by the more dominant students understand concept with $64.66 \%$ percentage, guess $14,10 \%$, misconception $7,14 \%$, and do not understand concept $14,10 \%$.
\end{abstract}

Keywords: Contextual Module, Multirepresentation, Understanding of Physics Concepts

\begin{abstract}
Abstrak: Pengaruh Penggunaan Modul Kontekstual Berbasis Multirepresentasi pada Pembelajaran Hukum Gravitasi Newton terhadap Pemahaman Konsep Siswa. Penelitian ini bertujuan untuk mendeskripsikan pengaruh penggunaan modul kontekstual berbasis multirepresentasi pada pembelajaran Hukum Gravitasi Newton terhadap pemahaman konsep siswa. Penelitian ini dilakukan di SMAN 14 Bandar Lampung dengan desain Quassy Experimental jenis pretest-posstest control grup design. Hasil uji $N$-gain yang telah dilakukan menunjukkan bahwa rata-rata $N$-gain dari kelas yang menggunakan modul kontekstual berbasis multirepresentasi lebih tinggi, yaitu 0,75 dengan kategori tinggi. Hasil uji hipotesis diperoleh bahwa terdapat perbedaan peningkatan pemahaman konsep fisika antara siswa yang belajar menggunakan modul kontekstual berbasis multirepresentatif dengan yang menggunakan buku cetak sekolah. Untuk mengukur pemahaman konsep siswa menggunakan metode Certainty of Respone Index (CRI). Nilai pemahaman konsep siswa ditunjukkan dengan siswa lebih dominan paham konsep dengan persentase $64,66 \%$, menebak $14,10 \%$, miskonsepsi $7,14 \%$, dan tidak paham konsep $14,10 \%$.
\end{abstract}

Kata Kunci: Modul Kontekstual, Multirepresentasi, Pemahaman Konsep Fisika 


\section{PENDAHULUAN}

Pencapaian dalam menyiapkan manusia yang memiliki daya saing yang tinggi adalah dengan meningkatan kualitas pendidikan. Menurut Setiyawan (2016), pendidikan merupakan sesuatu yang dinamis, sehingga tidak menutup kemungkinan dilakukan perubahan agar menjadi lebih baik serta mampu mengakomodasi kemajuan ilmu pengetahuan dan teknologi. Pemerintah melakukan upaya dengan adanya kemajuan ilmu pe-ngetahuan dan teknologi, yaitu dengan mengubah kurikulum KTSP menjadi Kurikulum Berbasis Kompetensi. Standar proses yang digunakan juga mengalami perubahan dimana pem-belajaran yang dilakukan meng-gunakan pendekatan saintifik dan juga pembelajaran lebih mengaktifkan siswa, pemahaman, kemampuan berpikir ktiris, logis, maupun matematis siswa (Sinambela, 2013).

Perubahan standar proses membuat pembelajaran di sekolah semakin pesat, dimana pembelajaran yang digunakan sekarang ini adalah pembelajaran kontekstual. Hasibuan (2014) mengatakan pembelajaran kontekstual merupakan proses pembelajaran yang holistik dan bertujuan membantu siswa untuk memahami makna materi ajar dan mengaitkannya dengan konteks ke-hidupan mereka sehari-hari, sehingga siswa memiliki pengetahuan yang dinamis dan fleksibel untuk meng-konstruksi sendiri secara aktif pemahamannya.

Menurut Depdiknas (2003: 5) pembelajaran kontekstual melibatkan tujuh komponen utama dari pembelajaran produktif yaitu konstruktivisme (constructivism), bertanya (questioning), menemukan (inquiry), masyarakat belajar (learning community), pemodelan (modelling), refleksi (reflection) dan penilaian yang sebenarnya (authentic assessment).

Pembelajaran kontekstual yang dilakukan akan membuat siswa dapat mudah memahami pelajaran di sekolah terutama pada mata pelajaran Fisika. Menurut Pohan, dkk. (2014) pendekatan kontekstual membantu siswa mampu merelevansi teori belajar dengan kehidupan nyata yang diintegrasikan dalam materi pembelajaran dengan tujuan untuk mampu memecahkan masalah yang bersifat simulatif (nyata) dan siswa langsung mempraktekkan materi yang dipelajari dalam konteks nyata di lingkungan masyarakat. Hal yang harus diperhatikan bagi setiap guru dalam menggunakan pembelajaran kontekstual, yaitu belajar bagi siswa adalah proses mencari keterkaitan atau keterhubungan antara hal-hal yang baru dengan hal-hal yang sudah diketahui. Jadi, peran guru adalah membantu agar setiap siswa mampu menemukan keterkaitan antara pengalaman baru dengan pengalaman sebelumnya (Bukhori, 2013).

Pembelajaran Fisika akan menjadi lebih mudah jika siswa mampu memahami konsep yang ada. Fisika itu sendiri adalah ilmu yang mempelajari tentang fenomena-fenomena alam. Pemahaman konsep dalam Fisika sangat penting, karena mempelajari Fisika kita bukan hanya menguasai pengetahuan yang berupa fakta maupun prinsip saja, akan tetapi mempelajari proses penemuan yang dapat dilihat dan dibuktikan dalam kehidupan seharihari. Konsep itu sendiri adalah suatu pemikiran dari seseorang atau sekelompok orang yang diperoleh kejadian-kejadian, kegiatan-kegiatan, atau hubungan-hubungan yang nantinya akan menjadi prinsip, hukum, atau teori (Utami dkk, 2017). 
Menurut Lubis (2014) pemahaman bukan hanya sekedar tahu, tetapi juga menginginkan siswa yang belajar dapat memanfaatkan atau mengaplikasikan apa yang telah dipahaminya. Maka dapat dikatakan bahwa pemahaman konsep adalah kemampuan siswa dalam menguasai suatu konsep, bukan hanya menghapal materi yang dipelajari saja tetapi juga siswa dapat menganalisis, menerapkan, dan memahami dengan benar sehingga dapat mengungkapkan kembali dalam bentuk yang lebih mudah dipahami.

Mauke, dkk. (2013) juga berpendapat bahwa proses pembelajaran siswa harus memiliki pemahaman tentang konsep, karena konsep-konsep merupakan dasar bagi proses-proses mental yang lebih tinggi untuk merumuskan prinsip-prinsip dan generalisasi. Proses pemecahkan masalah siswa diperlukan aturan yang relevan dan aturan yang didasarkan pada konsep yang diperolehnya.

Siswa bukan hanya dituntut untuk menggunakan pembelajaran kontekstual saja tetapi juga harus mempunyai kemampuan multirepresentasi. Multirepresentasi berarti merepresentasi ulang konsep yang sama dengan bentuk atau format yang berbeda termasuk verbal, grafik, gambar, dan matematika (Waldrip dkk, 2007).

Hal ini didasarkan juga oleh penelitian Suhandi \& Wibowo (2012) yang menyatakan bahwa penanaman suatu konsep dalam bentuk multirepresentasi dapat lebih membantu siswa dalam memahami konsep yang dipelajari. Masih banyak siswa yang dapat menyelesaikan permasalahan dalam bentuk matematis tetapi tidak dapat menyelesaikan soal yang berbentuk grafik atau gambar, meskipun masih dalam konsep yang sama. Jika sajian konsep hanya ditekankan pada satu atau dua representasi saja, maka akan menguntungkan sebagian siswa dan tidak menguntungkan bagi yang lainnya. Misalnya sajian konsep hanya dinyatakan dalam representasi verbal, maka siswa yang lebih menonjol kemampuan spasialnya akan sulit memahami konsep yang disajikan. Dapat dikatakan bahwa representatif yang digunakan bukan hanya satu melainkan dari beberapa representatif untuk meningkatkan pemahaman konsep siswa.

Kress et al. dalam Abdurrahman, dkk. (2008) menyatakan bahwa secara naluriah, manusia menyampaikan, dan menginterpretasikan melalui berbagai cara penyampaian dan berbagai komunikasi, baik dalam bacaan, pembicaraan, maupun tulisan. Meskipun model linguistic berfokus pada oral dan teks sering dianggap sebagai kunci model komunikasi, model-model lain seperti visual, symbol, gambar tidak bergerak, animasi grafik, model-model fisik, isyarat dan gerakan juga mempunyai peran yang penting dalam proses pembelajaran.

Menurut Ainswort dalam Sunyono (2013) multirepresentasi memiliki tiga fungsi utama, yaitu sebagai pelengkap, pembatas inter-pretasi, dan pembangun pemahaman. Melatih pengalaman pembelajaran siswa yang multirepresentasi dapat dilakukan dengan menyusun bahan ajar. Bahan ajar adalah segala bentuk bahan yang digunakan dalam pelaksanaan kegiatan belajar dan mengajar di kelas. Bahan ajar dapat digunakan oleh guru maupun siswa sehingga membantu proses pembelajaran. Modul merupakan salah satu bahan ajar yang dimanfaatkan dalam kegiatan belajar dan mengajar.

Menurut Ardi, dkk. (2015) menyebutkan bahwa modul adalah sebuah bahan ajar yang disusun secara sistematis dengan bahasa yang mudah 
dipahami siswa sesuai tingkat pengetahuan dan usia mereka, agar mereka dapat belajar sendiri (mandiri) dengan bantuan atau bimbingan yang minimal dari pendidik. Penggunaan modul tersebut dapat memudahkan siswa dalam pemahaman konsep pada pembelajaran. Hal ini juga didukung oleh pendapat Pratama, dkk. (2016) bahwa modul yang digunakan akan berpengaruh terhadap hasil belajar siswa dan kemandirian siswa.

Salah satu bahan ajar berupa modul kontekstual berbasis multirepresentasi dapat meningkatkan pemahaman konsep siswa, karena dalam modul tersebut siswa dapat belajar dengan beberapa representasi dan komponen pembelajaran. Modul tersebut juga mampu menarik perhatian siswa dan dapat mendorong motivasi belajar siswa dalam menemukan hubungan materi dengan situasi kehidupan nyata (Fatmala dkk, 2017). Maka, dapat dikatakan bahwa bahan ajar berupa modul yang baik harus disusun secara sistematis dan variatif dengan adanya banyak representasi atau multirepresentasi (Abdurrahman dkk, 2011). Berdasarkan pemaparan tersebut maka metode yang baik dilaksanakan untuk meningkatkan pemahaman konsep siswa, yaitu dengan pembelajaran menggunakan modul berbasis multi-representasi.

Menurut Hasan dalam Hakim, dkk. (2012) salah satu cara pengukuran pada pengukuran pemahaman konsep selain dengan analisis hasil belajar bisa menggunakan soal berbasis modifikasi Certainty of Respon Index (CRI). CRI biasanya didasarkan pada suatu skala, sebagai contoh skala enam (0-5), 0 jika totally guess answer, 1 jika almost guess, 2 jika not sure, 3 jika sure, 4 jika almost certain, dan 5 jika certain.

Siswa yang mengalami miskonsepsi atau tidak tahu konsep dapat dibedakan secara sederhana dengan cara membandingkan benar atau tidaknya jawaban dengan tinggi rendahnya indeks kepastian jawaban Jika jawaban siswa benar dengan CRI rendah artinya tidak tahu konsep (lucky guess) atau menebak, jika jawaban benar dengan CRI tinggi artinya paham konsep. Setelah itu, jika jawaban siswa salah dengan CRI rendah artinya tidak tahu konsep dan jika jawaban salah dengan CRI tinggi artinya miskonsepsi.

Miskonsepsi masih sering terjadi pada siswa, hal ini masih dapat terjadi mungkin karena kemampuan siswa atau cara mengajar guru. Menurut Lusiana, dkk. (2015) kiat yang tepat untuk membantu siswa mengatasi miskonsepsi adalah mencari bentuk kesalahan yang dimiliki siswa itu, mencari sebab-sebabnya dan dengan pengertian itu menentukan cara yang sesuai. Secara umum, untuk dapat membantu siswa mengatasi miskonsepsi, pertama-tama guru perlu mengerti kerangka berpikir siswa maka kita dapat mengetahui tepat dimana letak miskonsepsi siswa dan kita dapat membantunya.

Selain menggunakan soal pilihan ganda berbasis CRI, pemahaman konsep juga dapat diukur dengan taksonomi bloom dalam ranah kognitif yang telah direvisi Anderson dan Krathwohl, yaitu mengingat (remember), memahami atau mengerti (understand), menerapkan (apply), menganalisis (analyze), mengevaluasi (evaluate), menciptakan (create).

Tujuan dari penelitian ini adalah untuk mendeskripsikan pengaruh penggunaan modul kontekstual berbasis multirepresentasi pada pembelajaran Hukum Gravitasi Newton terhadap pemahaman konsep siswa

\section{METODE PENELITIAN}


Populasi dalam penelitian ini adalah seluruh kelas X SMA Negeri 14 Bandarlampung semester genap tahun ajaran 2017/2018. Desain penelitian ini adalah Quassy Experimental Design dengan jenis pretest-posstest control grup design. Penelitian ini menggunakan dua kelas, yaitu kelas kontrol dan kelas ekperimen. Kelas kontrol diberikan perlakuan, yaitu menggunakan buku cetak sekolah dan kelas ekperimen diberikan pembelajaran menggunakan modul kontekstual berbasis multirepresentasi. Pada desain ini masing-masing kelas, yaitu kelompok kontrol dan kelompok eksperimen memperoleh tes awal (pretest) sebelum diberikan perlakuan tes akhir (posttest) setelah diberikan perlakuan. Secara umum desain penelitian yang akan digunakan dapat dilihat pada Gambar 1.

\begin{tabular}{|lll|}
\hline $\mathrm{O}_{1}$ & $\mathrm{X}_{1}$ & $\mathrm{O}_{2}$ \\
\hline $\mathrm{O}_{3}$ & $\mathrm{X}_{2}$ & $\mathrm{O}_{4}$ \\
\hline
\end{tabular}

Gambar 1. Desain Eksperimen

Penelitian ini terdapat dua varibel, yaitu variabel bebas dan variabel terikat. Variabel bebas adalah penggunaan modul kontekstual berbasis multirepresentasi. Variabel terikatnya adalah pemahaman konsep siswa. Instrumen penelitian yang digunakan pada penelitian ini adalah hasil belajar siswa menggunakan soal tes berbentuk pilihan jamak beralasan dan soal uraian. Pengukuran pemahaman konsep siswa menggunakan metode CRI untuk pilihan ganda dan penilaian pemahaman untuk uraian menggunakan rubik holisttik skala 0-4. Sebelum instrumen digunakan dalam sampel, harus diuji terlebih dahulu validitas dan reliabilitasnya.
Data dalam penelitian ini adalah data pemahaman konsep siswa yang diperoleh dari proses pembelajaran. Data tersebut kemudian dianalisis dengan melakukan uji $N$-gain, uji normalitas, uji homogenitas, dan uji Independent Sample T-Test. N-gain diperoleh dari hasil pengungaran skor posttest dengan skor pretest dibagi oleh skor maksimum dikurangi skor pretest. Data dari $N$-gain tersebut kemudian digunakan untuk melihat peningkatan hasil belajar siswa dari kelas kontrol maupun kelas eksperimen, dimana data tersebut harus terdistribusi normal. Dasar pengambilan keputusan dalam uji normalitas, yaitu jika KolmogorovSmirnov nilai sig $>0,05$ dikatakan data terdistribusi normal dan jika nilai sig $<0,05$ data tidak berdistribusi normal.

Uji homogenitas dilakukan untuk mengetahui sama tau tidaknya varian dari populasi. Jika kedua kelas mempunyai varians yang tidak jauh berbeda (sama) maka kedua kelas dikatakan homogen, begitupun sebaliknya. Apabila kedua kelas homogen, dilakukan uji Independent Sample T-test untuk mengetahui ada atau tidaknya perbedaan peningkatan pemahaman konsep siswa dari kedua kelas. Berpedoman berdasarkan nilai signifikansi atau nilai probabilitas, jika nilai sig $>0,05$ maka $\mathrm{H}_{0}$ diterima dan apabila nilai sig $<0,05$ maka $\mathrm{H}_{0}$ ditolak.

\section{HASIL PENELITIAN}

\begin{tabular}{llr}
\multicolumn{2}{c}{ Penelitian ini mengenai } \\
pengaruh penggunaan modul
\end{tabular} kontekstual berbasis multirepresentasi pada pembelajaran hukum gravitasi newton terhadap pemahaman konsep siswa yang dilaksanakan di SMA Negeri 14 Bandarlampung dengan dua kelas yang digunakan. Proses pembelajaran berlangsung selama dua kali tatap muka dengan alokasi waktu 3 jam 
pelajaran yang terdiri atas 45 menit per jam pelajaran. Pada penelitian ini kelas kontrol yang digunakan adalah kelas $\mathrm{X}$ MIA 2 dengan 25 siswa dan proses pembelajaran dilakukan menyesuaikan jadwal pelajaran fisika, yaitu hari Jumat. Kelas eksperimen yang digunakan pada penelitian ini adalah kelas X MIA 1 dengan 28 siswa dan proses pembelajaran berlangsung pada hari Kamis. Hasil yang diperoleh dari penelitian ini berupa data kuantitatif yang selanjutnya akan diolah.

Sebelum melakukan pengumpulan data di lapangan, instrumen soal yang akan digunakan diuji terlebih dahulu untuk mengetahui layak atau tidaknya soal tersebut digunakan untuk penelitian dengan menggunakan uji validitas, terdapat 12 soal yang valid dari 19 soal pilihan ganda dan terdapat 5 soal yang valid dari 5 soal uraian yang dujikan dan mewakili semua indikator. Selanjutnya uji reliabilitas dilakukan, diperoleh bahwa instrumen soal yang digunakan bersifat reliabel untuk soal pilihan ganda dan sangat reliabel untuk soal uraian.

Peningkatan hasil belajar dari kedua kelas akibat dari perlakuan tertentu, yaitu dengan menggunakan nilai $\mathrm{N}$-gain. Nilai rata-rata peningkatan hasil belajar dari kelas eksperimen lebih tinggi daripada kelas kontrol. Kelas eksperimen berada pada kategori tinggi yakni 0,75 dan kelas kontrol berada pada kategori sedang dengan diperoleh rata-rata 0,58. Hal ini dapat menunjukkan bahwa adanya pengaruh penggunaan modul kontekstual berbasis multirepresentasi pada membelajaran hukum newton tentang gravitasi.

Nilai rata-rata pemahaman konsep siswa dari kedua kelas dikatakan berdistribusi normal. Kelas kontrol dengan nilai Sig. 0,200 yang berarti di atas 0,050 dan untuk kelas eksperimen nilai dari Sig. 0,196 yang juga di atas 0,050 , seperti terlihat pada Tabel 1 . Berdasarkan hasil tersebut, maka dapat disimpulkan bahwa data nilai pemahaman konsep siswa dari kedua kelas berdistribusi normal.

Nilai signifikasi dari uji homogenitas diperoleh $F_{\text {hitung }}$ sebesar 0,261 yang artinya lebih dari 0,050. Hasil yang diperoleh tersebut dapat disimpulkan bahwa data nilai pemahaman konsep siswa dari kedua kelas memiliki varian sama.

Pengujian hipotesis dilakukan agar dapat menentukan diterima atau tidaknya hipotesis penelitian. Pada penelitian ini, uji hipotesis menggunakan teknik Independent Sample Ttest. Nilai Sig. (2-tailed) yang diperoleh adalah 0,000 yang berarti kurang dari 0,050 maka dapat disimpulkan bahwa $\mathrm{H}_{1}$ diterima. Seperti terlihat pada Tabel 2.

Tabel 1. Hasil Uji Normalitas $N$-gain

\begin{tabular}{ccccccc}
\hline \multirow{2}{*}{ Kelas } & Tes & Tertinggi & Terendah & $\begin{array}{c}\text { Rata- } \\
\text { rata }\end{array}$ & $N$-gain $\begin{array}{c}\text { Asym.Sig(2- } \\
\text { tailed) }\end{array}$ \\
\hline \multirow{2}{*}{ Kontrol } & Awal & 33,33 & 0,00 & 16,00 & 0,58 & 0,200 \\
& Akhir & 80,00 & 33,33 & 64,67 & & \\
\multirow{2}{*}{ Eksperimen } & Awal & 33,33 & 0,00 & 16,31 & 0,75 & 0,196 \\
& Akhir & 93,33 & 43,33 & 79,64 & & \\
\hline
\end{tabular}


Tabel 2. Hasil Uji Independent Sample T-test Pemahaman Konsep Siswa

\begin{tabular}{lccccc}
\hline & \multicolumn{3}{c}{$\begin{array}{c}\text { Levene's Test for } \\
\text { Equality of Variances }\end{array}$} & \multicolumn{3}{c}{ T-Test for Equality of Means } \\
\cline { 2 - 6 } & $\mathrm{F}$ & $\mathrm{Sig}$ & $\mathrm{T}$ & $\mathrm{Df}$ & Sig. 2-tailed \\
\hline $\begin{array}{l}\text { Equal variances } \\
\text { assumed }\end{array}$ & 1,29 & 0,26 & $-6,27$ & 51 & 0,000 \\
\hline
\end{tabular}

Tabel 3. Presentase Hasil Analisis Pemahaman Konsep

\begin{tabular}{lcccc}
\hline $\begin{array}{l}\text { Konsep Hukum Gravitasi } \\
\text { Newton }\end{array}$ & $\begin{array}{c}\text { Paham } \\
\text { Konsep }\end{array}$ & Menebak & Miskonsepsi & $\begin{array}{c}\text { Tidak } \\
\text { Paham }\end{array}$ \\
& $(\%)$ & $(\%)$ & $(\%)$ & $(\%)$ \\
\hline Hukum Gravitasi Newton & 82,1 & 16,1 & 0 & 1,8 \\
Medan Gravitasi & 73,2 & 15,2 & 3,6 & 8 \\
Potensial Gravitasi & 75 & 25 & 0 & 0 \\
Hukum Kepler & 25 & 7,1 & 14,3 & 53,6 \\
Kelajuan Benda untuk & 68 & 7,1 & 17,8 & 7,1 \\
mengorbit Planet & & & & \\
\hline
\end{tabular}

Hasil pengujian tersebut disimpulkan bahwa "terdapat perbedaan peningkatan pemahaman konsep Fisika antara siswa yang belajar menggunakan modul kontekstual berbasis multirepresentasi dengan yang menggunakan buku cetak sekolah". Sehingga pembelajaran menggunakan modul kontekstual berbasis multirepresentasi berpengaruh terhadap hasil belajar siswa.

Pemahaman konsep siswa dapat diidentifikasi dengan menggunakan metode CRI. Penilaian pemahaman konsep siswa untuk 10 soal pilihan ganda beralasan menggunakan metode CRI dan untuk 5 soal uraian menggunakan rubrik holistik. Penentuan untuk kriteria siswa yang paham konsep, lucky guess (menebak), miskonsepsi, dan tidak paham konsep dilihat dari jawaban nilai CRI yang diberikan siswa. Tabel 3, memperlihat- kan kategori siswa yang paham konsep, lucky guess (menebak), miskonsepsi, dan tidak tahu konsep pada materi Hukum Gravitasi Newton.

Tabel 3 menampakkan rata-rata tingkat pemahaman konsep siswa pada kelas eksperimen lebih dominan siswa paham konsep dengan persentase $64,66 \%$, dilanjutkan dengan siswa lucky guess $14,10 \%$, miskonsepsi $7,14 \%$ dan $14,10 \%$ tidak paham konsep.

\section{PEMBAHASAN}

Berdasarkan hasil perhitungan, diketahui bahwa rata-rata hasil belajar siswa saat posttest pada kelas eksperimen lebih tinggi dengan nilai 81,99 daripada kelas kontrol dengan nilai 65,07 . Hasil rata-rata $N$-gain pada kelas kontrol dengan menggunakan buku cetak ajar yang ada di sekolah sebesar 0,58 yang artinya kategori sedang. Persentase dari kelas kontrol, 
yaitu $16 \%$ memperoleh kategori tinggi dan $84 \%$ siswa memperoleh kategori sedang, sedangkan rata-rata $N$-gain dari kelas ekperimen dengan menggunakan modul kontesktual berbasis multirepresentasi sebesar 0,75 yang artinya kategori tinggi. Persentase dari kelas eksperimen, yaitu 64,3\% memperoleh kategori tinggi dan $35,7 \%$ siswa memperoleh kategori sedang.

Hasil uji hipotesis dengan menggunakan uji Independent Sample T-test yang sudah dilakukan, nilai Sig. (2-tailed) yang diperoleh adalah 0,000 yang berarti kurang dari 0,050. Berdasarkan hasil tersebut disimpulkan bahwa terdapat perbedaan peningkatan pemahaman konsep Fisika antara siswa yang belajar menggunakan modul kontekstual berbasis multirepresentasi dengan yang menggunakan buku cetak ajar yang artinya ada pengaruh yang signifikan dari penggunaan modul kontekstual berbasis multirepresentasi.

Hasil yang diperoleh tersebut dikatakan bahwa modul tersebut dapat memudahkan siswa dalam memahami konsep materi Hukum Gravitasi Newton, jadi untuk mengkonfirmasi hasil penelitian ini maka dibandingkan dengan penelitian yang relevan. Hasil penelitian yang dilakukan oleh Asfiah, dkk. (2013) yakni penggunaan modul kontekstual dapat membantu siswa mengaitkan materi dengan kehidupan nyata sehingga dapat memotivasi siswa untuk belajar dan materi dalam modul yang dipadukan dapat membantu siswa dalam memperoleh pengetahuan yang lebih luas.

Penelitian Said \& Jafar (2015) juga memperoleh bahwa hasil belajar siswa menggunakan modul Fisika berbasis kontekstual dapat mencapai ketuntasan belajar siswa. Respons siswa terhadap modul Fisika berbasisis kontekstual menunjukkan bahwa 97\% dari jumlah keseluruhan siswa memberi respons positif dan sangat positif.

Rata-rata hasil belajar dari kelas eksperimen lebih tinggi daripada kelas kontrol dan pada penelitian ini hasil $N$ gain kelas eksperimen masuk ke dalam kriteria tinggi. Hasil penelitian ini relevan dengan penelitian Mauke, dkk. (2013) yaitu model pembelajaran yang memiliki prinsip konstruktivistik adalah model pembelajaran kontekstual. Siswa membangun pengetahuannya sendiri melalui proses mengalami, sehingga dapat menumbuhkan pemahaman konsep dalam proses belajar mengajar yang mempengaruhi peningkatan hasil belajar.

Suhandi \& Wibowo (2012) juga berpendapat bahwa tampilan berbagai representasi dalam penanaman suatu konsep akan dapat lebih membantu siswa memahami konsep yang dipelajari. Hal ini terkait dengan setiap siswa memiliki kemampuan spesifik yang lebih menonjol dibanding kemampuan lainnya.

Penelitian ini juga untuk mengetahui peningkatan hasil belajar pada kelas eksperimen. tingkat pemahaman konsep dibagi menjadi 4, yaitu paham konsep, lucky guess atau menebak, miskonsepsi, dan tidak paham konsep. Pengujian pemahaman konsep dilakukan untuk jawaban kelas eksperimen dari hasil posttest, diperoleh bahwa 64,66\% siswa paham konsep, siswa yang menebak $14,10 \%$, siswa yang miskonsepsi $7,14 \%$ dan $14,10 \%$ tidak paham konsep, seperti pada Gambar 2. 


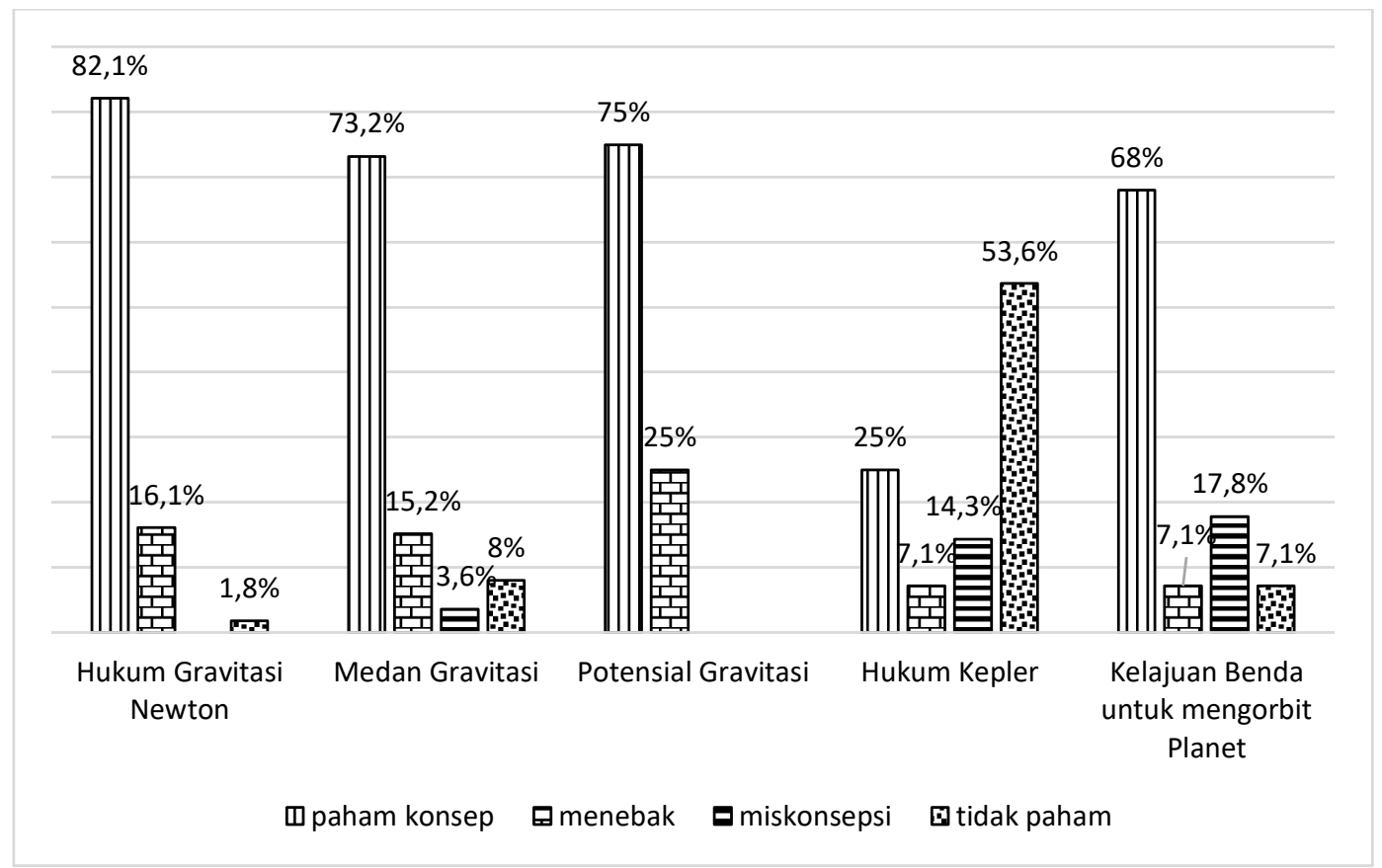

Gambar 2. Grafik Pemahaman Konsep Siswa pada Materi Hukum Gravitasi Newton

Pada butir soal mengenai Hukum Gravitasi Newton, yaitu pada butir soal nomor 1, 2, 9 dan 11. Siswa tidak paham konsep banyak terjadi pada butir soal nomor 11 sebesar 7,10\%. Berdasarkan wawancara yang dilakukan terhadap siswa yang mengalami miskonsepsi, penyebabnya adalah siswa beranggapan bahwa jarak antara benda $\mathrm{M}$ dan benda $4 \mathrm{M}$ adalah d, sehingga untuk mengetahui letak bintang ketiga dari $M$ yaitu dengan membagi dua nilai d, yaitu $1 / 2$ d. Pada butir soal nomor 1 siswa yang paham konsep 89,3\% karena telah melakukan percobaan menggunakan aplikasi Phet Simulation.

Pada butir soal mengenai Medan Gravitasi, yaitu pada butir soal nomor 3, 4, 5 dan 7. Miskonsepsi banyak terjadi pada butir soal nomor 3 dan 5, yaitu sebesar 3,6\% dan 7,1\%, lalu yang tidak paham konsep 7,1\% dan 17,9\%. Pada butir soal nomor 5 siswa mengalami miskonsepsi dan tidak paham, penyebabnya adalah siswa beranggapan bahwa semakin tinggi suatu tempat maka kuat medan gravitasinya juga akan semakin besar. Padahal hubungan antara ketinggian dengan kuat medan gravitasi adalah berbanding terbalik. Pada butir soal nomor 5 terjadi miskonsepsi dan tidak paham, karena masih ada siswa yang belum memahami bahwa berat dan massa itu berbeda.

Pada butir soal nomor 8, 12, 13 dan 14. Miskonsepsi banyak terjadi pada butir soal nomor 8 sebesar 14,3\% dan tak paham konsep 39,3\%. Siswa mengalami mikonsepsi dan tidak tahu konsep karena beranggapan bahwa planet merkurius paling dekat dengan matahari maka berat badan paling ringan ketika di planet merkurius. Pada materi Medan Gravitasi ini siswa paling banyak paham konsep pada butir soal nomor 12,13 , dan 14 sebesar $96,4 \%$.

Pada butir soal mengenai potensial, yaitu pada butir soal nomor 6 tidak ada siswa yang mengalami miskonsepsi dan tidak paham konsep. Siswa yang paham konsep lebih besar dengan $75 \%$. Siswa tidak mengalami miskonsepsi pada soal ini karena siswa telah melakukan percobaan pada saat 
pembelajaran, sehingga siswa menjadi paham.

Pada butir soal mengenai hukum kepler dan kelajuan benda mengorbit planet, yaitu pada butir soal nomor 10 dan 15. Miskonsepsi dan tidak paham konsep terjadi pada kedua soal tersebut, persentasi miskonsepsi sebesar 14,3\% dan $17,8 \%$, lalu yang tidak paham konsep sebesar 53,6\% dan 7,1\%.

Siswa mengalami miskonsepsi dan tidak paham konsep karena beranggapan bahwa jari-jari elips dan lingkaran itu sama, maka jarak ke titik pusat (matahari) akan selalu sama. Tetapi, elips memiliki jari-jari yang berbeda begitupula dengan kecepatan gerak juga planet akan bervariasi. Siswa juga masih belum mengerti dan miskonsepsi tentang titik perihelion dan aphelion. Berdasarkan penjelasan tersebut diperoleh bahwa siswa masih mengalami miskonsepsi dan tak paham konsep pada submateri hukum kepler dan kelajuan benda untuk mengorbit planet. Hal ini terjadi karena siswa kesulitan dalam menganalisis secara matematis, verbal, dan gambar dari hukum kepler dan kelajuan benda dalam mengorbit planet.

Berdasarkan analisis pemahaman konsep diperoleh bahwa masih cukup banyak siswa yang mengalami miskonsepsi. Penyebab dari miskonsepsi ini karena faktor siswa itu sendiri dan guru, yaitu kemampuan

\section{DAFTAR RUJUKAN}

Abdurrahman, Apriliyawati, \& Payudi. 2008. Limitation of Representation Mode in Learning Gravitational Concept and Its Influence Toward student Skill Problem Solving. Proceeding of The $2^{\text {nd }}$ International Seminar on Science Education. PHY-31: 373-377. siswa dalam menalar soal dan cara mengajar guru. Penelitian yang dilakukan oleh Lusiana, dkk. (2015) juga memperoleh hasil yang sama, yaitu penyebab dari miskonsepsi berasal dari cara mengajar guru dan siswa itu sendiri. Maka, solusi dalam mengatasi miskonsepsi adalah guru perlu mengerti kerangka berpikir siswa. Mengetahui cara berpikir, cara mengungkap dan bagaimana gagasan siswa, maka guru dapat mengetahui tepat dimana letak miskonsepsi siswa dan kita dapat membantunya.

\section{SIMPULAN}

Berdasarkan hasil penelitian dan pembahasan yang telah diuraikan, maka dapat disimpulkan bahwa terdapat pengaruh yang signifikan dalam penggunaan modul kontekstual berbasis multirepresentasi pada pembelajaran Hukum Gravitasi Newton terhadap pemahaman konsep siswa yang ditunjukkan oleh perbedaan rata-rata nilai $N$-gain pada kelas eksperimen yakni 0,77 dengan kategori peningkatan yang tinggi dan pemahaman konsep fisika siswa pada pembelajaran menggunakan modul kontekstual berbasis multirepresentasi ditunjukan dengan persentase, yaitu siswa yang paham konsep sebesar 64,66\%, menebak sebesar $14,10 \%$, sedangkan miskonsepsi $7,14 \%$ dan tak paham konsep sebesar 14,10\%.

Abdurrahman, Liliasari, A. R., \& Waldrip, B. 2011. Implementasi Pembelajaran Berbasis Multi Representasi untuk Peningkatan Penguasaan Konsep Fisika Kuantum. Cakrwala Pendidikan. 2 (3): 159-165.

Ardi, A., Nyeneng, I. D. P., \& Ertikanto, C. 2015. Pengembangan Modul Pembelajaran Fisika Berbasis Inkuri Terbimbing pada Materi 
Pokok Suhu dan Kalor. Jurnal Pembelajaran Fisika. 3 (3): 6465.

Asfiah, N., Mosik, \& Purwantoyo, E. 2013. Pengembangan Modul IPA Terpadu Kontekstual pada Tema Bunyi. Unnes Science Education Journal. 2 (1): 188-195.

Bukhori, M. A. F. 2013. Pembelajaran Fisika dengan CTL Melalui Pengalaman Empiris: Kasus Perbedaan Pemahaman Konsep Gerak Melingkar Pada Siswa Kelas X di SMA Negeri 4 Magelang, Jawa Tengah. Jurnal Berkala Fisika Indonesia. 5 (1): 7 9.

Depdiknas. 2003. Pendekatan Kontekstual. Jakarta: Departemen Pendidikan Nasional.

Fatmala, Nurul Etiya, I Dewa Putu Nyeneng, \& Wayan Suana. 2017. Pengembangan Modul Pembelajaran Kontekstual Berbasis Multirepresentasi pada Materi Hukum Newton Tentang Gravitasi. Jurnal Pembelajaran Fisika. 5 (4): 21-23.

Hakim, A., Liliasari, Kadarohman, A. 2012. Student Concept Understanding of Natural Products Chemistry in Primary and Secondary Metabolies Using the Data Collecting Technique of Modified CRI. International Online Journal of Education Sciences. 4 (3): 545-546.

Hasibuan, M. I. 2014. Model Pembelajaran CTL (Contextual Teaching and Learning). Jurnal Ilmu-ilmu Pendidikan dan Sains. 2 (1): 2-3.

Lubis, M. I. 2014. Pengaruh Model Pembelajaran Kooperatif Listening Team Terhadap Pemahaman Siswa di Sekolah Menengah Atas Negeri 1 Kuantan
Singingi. Jurnal Penelitian Sosial Keagamaan. 17 (2): 266-267.

Lusiana, N., Kurniawati, L., \& Mulyanto, A.B. 2015. Analisis Miskonsepsi Siswa Pokok Bahasan Momentum dan Impuls di Kelas XII IPA 4 SMA Negeri 4 Lubuklinggau Tahun Pelajaran 2015/2016.

Mauke, M., Sadia, I. W., \& Suastra, I. W. 2013. Pengaruh Model Contextual Teaching and Learning terhadap Pemahaman Konsep dan Kemampuan Pemecahan Masalah dalam Pembelajaran IPA-Fisika di MTS Negeri Negara. E-Journal Program Pascasarjana Universitas Pendidikan Ganesha. 3 (1): 2-4.

Pohan, J. E., Atmazaki, Agiustina. 2014. Pengembangan Modul Berbasis Pendekatan Kontekstual pada Menulis Resensi di Kelas IX SMP 7 Padang Bolak. Jurnal Bahasa, Sastra dan Pembelajaran. 2 (2): 1-11.

Pratama, D. R., Widiyatmoko, A., \& Wusqo, I. U. 2016. Pengaruh Penggunaan Modul Kontekstual Berpendekatan SETS terhadap Hasil Belajar dan Kemandirian Peserta Didik Kelas VII SMP. Unnes Science Education Journal. 5 (3): 1366-1376.

Said, G. A., \& Jafar, A. F. 2015. Penggunaan Modul Berbasis Kontekstual terhadap Hasil Belajar Fisika Peserta Didik pada Pokok Bahasan Hukum Newton Kelas VII MTS Madani Alauddin Paopao. Jurnal Pendidikan Fisika. 3 (2): 143-148.

Setiyawan, D., Indrowati, M., \& Nurmiyati. 2016. Perbandingan Model Pembelajaran Discovery Berbantu Peta Konsep dan Model Pembelajaran Discovery terhadap 
Pemahaman Konsep Materi

Protista Siswa Kelas X SMA

Negeri 1 Sukoharjo. Jurnal

Pendidikan. 5 (1): 51-52.

Sinambela, P. N. J. M. 2013. Kurikulum

2013 dan Implementasi dalam

Pembelajaran. Jurnal Unimed

Generasi Kampus. 6 (2): 17-29.

Suhandi, A. dan Wibowo, F.C. 2012.

Pendekatan Multirepresentasi

dalam Pembelajaran Usaha-

Energi dan Dampak terhadap

Pemahaman Konsep Mahasiswa.

Jurnal Pendidikan Fisika. 8 (1): 1-2.

Sunyono. 2013. Model Pembelajaran

Berbasis Multipel Representasi
(Model SiMaYang). Bandar Lampung: AURA Publishing.

Utami, R. U., Rosidin, U., \& Wahyudi, I. 2017. Pengaruh Penggunaan Elearning dengan Schoology Materi Gravitasi Newton terhadap Hasil Belajar Siswa. Jurnal Pembelajaran Fisika. 5 (2): 81-91

Waldrip, B. W., Prain, V., \& Carolan, J. 2007. Learning Junior Secondary Science Through Multi-Modal Representations. Electronic Journal of Science Education (SouthwesternUniversity). 11 (1): 86-105. 